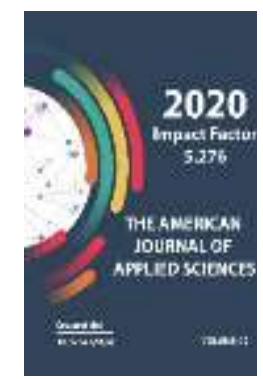

Journal Website: http://usajournalshub.c om/index,php/tajas

Copyright: Original content from this work may be used under the terms of the creative commons attributes 4.0 licence.

\section{Territorial Location Of Medical Services To The Population In The Republic Of Karakalpakstan}

\author{
Gaypova Roza Tursinbaevna \\ PhD Doctor Of Geography Teaching Methods Department Nukus State Pedagogical Institute \\ Named After Ajiniyaz, Uzbekistan \\ Uzaqbaev Qoblan Keunimjay Uli \\ Doctoral Student Geography Teaching Methods Department Nukus State Pedagogical \\ Institute Named After Ajiniyaz Nukus, Qaraqalpaqstan, Uzbekistan
}

\title{
ABSTRACT
}

This article analyzes the problems of staffing in clinics, hospitals and other stationary health care institutions, the current state of the health care system of the Republic of Karakalpakstan and gives some recommendations for their improvement.

\section{KEYWORDS}

Service, healthcare institutions, doctors, nurses, outpatient clinics, public healthcare

\section{INTRODUCTION}

Almost all of the reforms implemented by the state during the years of Independence are aimed at improving the social living conditions of the population. Social protection is one of the priorities of our state policy. In accordance with the Decree №5590, of the President of the Republic of Uzbekistan Sh. M. Mirziyoyev dated December 7, 2018 "On comprehensive measures to radically improve the healthcare system of the Republic of Uzbekistan", the relevant program was approved. Hospitals are being built and modernized in all regions. Along with public institutions, the field of private medicine is also developing rapidly. The range of medical activities has been increased from 50 to 126 and 634 private medical institutions were established last year due to a number of benefits. 
The American Journal of Applied Sciences

(ISSN - 2689-0992)

Published: November 18, 2020 | Pages: 28-33

Doi: https://doi.org/10.37547/tajas/Volume02Issue11-06

A centralized integrated system has been created in the area of emergency and ambulance that people refer to the most. The number of ambulance crews was increased from 818 to about 2,000 and brought closer to the population. The specialized fleet has been renewed.

We all know the socio-economic and environmental problems caused by the drying up of the Aral Sea in the country in recent years. The Aral Sea catastrophe is now one of the global problems, which affects the fate of not only the Republic of Uzbekistan, but also other countries in Central Asia. These problems are having a negative impact on human health and as a result have further increased the demand of the population for the health system.
Emerging environmental problems have led to a decrease in natural population growth rates, the emergence of various diseases, and an increase in the mortality rate among the population. To overcome this situation, it is necessary to develop and improve medical services. In addition, the development of the economy of our country depends mainly on labor resources. The health of the population plays an important role in the development of the economy. Because if medical care is highly developed, the economic efficiency in production will be high. In general, in order for a person to work normally, it is necessary to create the necessary conditions for him to further improve the areas of health, education, services.

\section{Health facilities of the Republic of Karakalpakstan}

Table 1 (As of January 1, 2020)

\begin{tabular}{|l|c|c|c|}
\hline \multicolumn{1}{|c|}{ Naming } & $\begin{array}{c}\text { Total } \\
\text { number }\end{array}$ & private & $\begin{array}{c}\text { Private in } \\
\text { total (\%) }\end{array}$ \\
\hline Total number of medical institutions: & $\mathbf{3 3 5}$ & $\mathbf{1 4 8}$ & $\mathbf{4 4 , 2}$ \\
\hline The number of medical staff in them & $\mathbf{2 5 6 8 2}$ & $\mathbf{5 8 2}$ & $\mathbf{2 , 3}$ \\
\hline of them: & & & \\
\hline - doctors & 4576 & 271 & 5,9 \\
\hline - nurses & 18027 & 311 & 1,7 \\
\hline - other employees & 3079 & - & - \\
\hline By types of medical institutions: & & & \\
\hline - Ambulance & $\mathbf{1 6}$ & - & - \\
\hline - outpatient clinics & $\mathbf{2 9 2}$ & $\mathbf{1 4 5}$ & $\mathbf{4 9 , 6}$ \\
\hline - family clinics of them & 79 & - & - \\
\hline - rural medical centers & 35 & - & - \\
\hline - capacity of outpatient clinics (1 shift) & 22165 & 1364 & 6,1 \\
\hline - - inpatient clinics & 43 & 3 & 7,0 \\
\hline - the number of places in them & 7319 & 96 & 1,3 \\
\hline - disinfection institutions & $\mathbf{8}$ & - & - \\
\hline
\end{tabular}

Source: Compiled by the author based on data from the Statistics Department of the Republic of Karakalpakstan 
The American Journal of Applied Sciences

(ISSN - 2689-0992)

Published: November 18, 2020 | Pages: 28-33

Doi: https://doi.org/10.37547/tajas/Volumeo2Issue11-06

During 1991-2020, the population of the Republic of Karakalpakstan increased from 1307.4 thousand to 1898.3 thousand people or $145.2 \%$. Population growth is due to its natural increase. Such a steady increase in population will further increase the demand for the social sphere.

According to the Statistics Department, 335 hospitals will serve the population in the Republic of Karakalpakstan in 2020, including 16 ambulances, 292 outpatient clinics, 43 inpatient clinics and 8 disinfection facilities, including 145 outpatient clinics and 3 inpatient clinics correspond to private medicine. The number of beds in inpatient clinics was 7319, and the capacity of outpatient clinics (1 shift) was 22165 people. The number of doctors (doctors) serving them is 4576 , medical staff with secondary education is 18027 people. This equates to 24 and 94.96 health workers per 10,000 population.

In recent years, significant changes have been observed in the health care system of the Republic of Karakalpakstan. For example, in 2000-2010, the number of doctors in all specialties decreased from 4.4 thousand to 3.6 thousand (81.1\%), and in 2020 increased to 4576. From 2000 to 2010 the number of hospitals increased from 88 to 51 (58.0\%), the number of dispensaries from 22 to 16 (72.7\%), the total number of beds for pregnant women increased from 1.3 thousand to 0.7 thousand (58.0\%). decreased. At the same time the total number of hospital beds increased from 7.2 thousand to 8.6 thousand people (119.4\%), the number of women's consultations (offices) in independent and other institutions increased from 148 to $223(150.7 \%)$, independent and other institutions. The number of children's polyclinics (departments) increased from 168 to $247(147.0 \%)$.

Territorial differences in the healthcare system in the Republic of Karakalpakstan are significant. For example, the average level of inpatient care in the country is 38.56 per 10,000 population. This figure was 92.56 in Nukus, 32.68 in Ellikkala district, 20.79 in Beruni district, 52.19 in Nukus district, 20.07 in Turtkul district, 34.26 in Kungrad district and 37.74 in Muynak district.

Table 2

\section{Hospitals in the Republic}

(in units)

\begin{tabular}{|c|c|c|}
\hline Naming & a year of 2018 & a year of 2019 \\
\hline Number of available hospitals & $\mathbf{4 2}$ & $\mathbf{4 3}$ \\
\hline The number of beds in hospitals & $\mathbf{7 2 8 9}$ & $\mathbf{7 3 1 9}$ \\
\hline Bed turnover during the year & $\mathbf{4 5 , 4}$ & $\mathbf{5 9 , 2}$ \\
\hline The number of employees in hospitals & $\mathbf{2 4 9 0 9}$ & $\mathbf{2 5 6 8 2}$ \\
\hline - doctors & 4408 & 4576 \\
\hline - nurses & 17654 & 18027 \\
\hline - other technical staff & 3054 & 3079 \\
\hline The number of people who applied to hospitals & 375389 & 377519 \\
\hline - Outpatients & 46805 & 47992 \\
\hline - Inpatients & 328584 & 329527 \\
\hline of which, the surgical method was used & 40991 & 41315 \\
\hline - recipients of medical advice rap & 46805 & 47992 \\
\hline - sent to other institutions by referral & 328584 & 329527 \\
\hline
\end{tabular}


The American Journal of Applied Sciences

(ISSN - 2689-0992)

Published: November 18, 2020 | Pages: 28-33

Doi: https://doi.org/10.37547/tajas/Volume02Issue11-06

\begin{tabular}{|c|c|c|}
\hline The number of deaths recorded at the hospital & 1329 & 1333 \\
\hline $\begin{array}{c}\text { of which, the number of infant deaths } \\
\text { The number of deaths (\%) relative to the total number of } \\
\text { inpatients }\end{array}$ & $\mathbf{2 1 4}$ & $\mathbf{0 , 4}$ \\
\hline $\begin{array}{c}\text { Number of born children } \\
\text { The number of deaths of children under 1 year of age }\end{array}$ & 40133 & 39607 \\
\hline $\begin{array}{c}\text { relative to the total number of children under 1 year of } \\
\text { age }\end{array}$ & 13,2 & 408 \\
\hline The number of deaths in maternity hospitals & 355 & 10,3 \\
\hline - maternal mortality & 11 & 330 \\
\hline - infant mortality & 345 & 13 \\
\hline
\end{tabular}

Table 3

Diseases and morbidity rates

\begin{tabular}{|c|c|c|}
\hline \multirow{2}{*}{ Names of the disease } & \multicolumn{2}{|c|}{ Morbidity (per 10 thousand of population) } \\
\cline { 2 - 3 } & in the year of 2018 & in the year of 2019 \\
\hline Infectious diseases: & 86,1 & 91,3 \\
\hline - AIDS & 0,7 & 0,6 \\
\hline - hepatitis & 8,0 & 5,8 \\
\hline - influenza & 0,1 & 0,1 \\
\hline - measles & - & 2,4 \\
\hline - chickenpox & 3,5 & 82,4 \\
\hline - others & 73,8 & 4589,5 \\
\hline Non-communicable diseases: & 4583,8 & 9,7 \\
\hline - diabetes mellitus & 8,9 & 81,5 \\
\hline - lodine deficiency & 109,9 & 516,2 \\
\hline - Diseases of the stomach and & 523,9 & 4073,4 \\
\hline intestines & 3941,1 & - \\
\hline others & & \\
\hline
\end{tabular}

In the Republic of Karakalpakstan, the average incidence of non-communicable diseases was 4,589.5 per 10,000 people, and the average incidence of infectious diseases was 91.3 per 10,000 people.
In recent years, the number of sports and health facilities in the Republic of Karakalpakstan is growing. The number and type of sports sections is constantly increasing. 
Table 4

Sports and health facilities

\begin{tabular}{|c|c|c|}
\hline Naming & Total number & $\begin{array}{c}\text { number of } \\
\text { private }\end{array}$ \\
\hline Sports facilities total: & 160 & - \\
\hline \multicolumn{3}{|l|}{ of them: } \\
\hline Stadiums & 19 & - \\
\hline Gyms & 57 & - \\
\hline of which women's shaping halls & - & - \\
\hline Number of sports clubs & 289 & - \\
\hline Number of participants & 19577 & - \\
\hline Swimming pools & 9 & - \\
\hline - open type & - & - \\
\hline - closed type & 9 & - \\
\hline Tennis courts & 22 & - \\
\hline Shooting ribs & & - \\
\hline Small football fields with artificial turf & 2 & - \\
\hline Other sports facilities & 51 & - \\
\hline Children and youth sports schools & 20 & - \\
\hline The number of participants in them & 32437 & - \\
\hline Sports (sections) available in the district & 253 & - \\
\hline - Rhythmic Gymnastics & 1667 & - \\
\hline - Light Athletics & 835 & - \\
\hline - Weightlifting (bodybuilding) & 1025 & - \\
\hline - basketball & 2190 & - \\
\hline - football and mini football & 2733 & - \\
\hline - wrestling & 2350 & - \\
\hline - Martial arts (karate, taekwondo, etc.) & 1911 & - \\
\hline - hand-to-hand combat (boxing) & 2694 & - \\
\hline - chess & 707 & - \\
\hline - others & 16072 & - \\
\hline
\end{tabular}

On the instructions of President Sh. M. Mirziyoev, extensive explanatory work is being carried out among the population to prevent diseases. Work is underway to organize walks in each neighborhood, to involve the entire population in physical culture, to promote healthy eating among the population.

The complications of the coronavirus COVID19 , which is shaking the world today, show that it is necessary to constantly increase the cost of medicine, to pay special attention to the training of doctors with high classification.

\section{REFERENCES}

1. Decree №5590. On comprehensive measures to radically improve the healthcare system of the Republic of Uzbekistan. 
2. (2020) The main indicators of socialeconomic development of the Republic of Karakalpakstan: Nukus.

3. (2020) Social-economic passport of the districts of the Republic of Karakalpakstan: Nukus. 